INTERNATIONAL JOURNAL OF RESEARCHES IN BIOSCIENCES, AGRICULTURE AND TECHNOLOGY (c) VISHWASHANTI MULTIPURPOSE SOCIETY (Global Peace Multipumose Socie ty) R. No. MH-659/13(N) www.vmsindia.org

\title{
A SURVEY OF PLANTS IN TRADITIONAL HOME REMEDIES IN BHANDRDARA AREAS OF AHMEDNAGAR DISTRICT (M.S.), INDIA
}

\author{
Ashok P. Salave ${ }^{1}$ and P. G. Reddy ${ }^{2}$ \\ 1Dept. of Botany, Shri Dnyaneshwar Mahavidyalaya, Newasa, Ahmednagar-414603 \\ ${ }^{2}$ Research Centre of Botany, P.V.P. College, Pravaranagar (Loni), Ahmednagar-413713 \\ salave_ap@yahoo.com
}

\begin{abstract}
:
The present communication reveals the traditional herbal remedies practiced in Akole tahasil areas of the Ahmednagar district against various liver diseases and disorders from Maharashtra, India. In all total 19 plant species belonging to 16 genera from 14 angiosperm families use d for treatment of certain human ailments and disorders have been documented. Of these, uses of --plant species found unknown or less known to India.
\end{abstract}

Keywords: Folklore, Home Remedies, toothache, Bhandardara

\section{Introduction:}

In India, the interactions between the traditional healers and their surroundings i.e. plants have greatly contributed in human civilization. Man himself has been using plants several plants for his healthcare [1]. These interactions have contributed greatly to the development [2], survival and welfare of human race on the earth planet. Scientific study of these interactions with a special focus on the traditional knowledge regarding use of plants and their produce for human welfare is called as ethnobotany.

In recent years, it has been realized that traditional herbal drugs are going to play a very significant role in curing certain acute and chronic diseases and disorders. Most of the modern synthetic drugs and medicines have attacked the targets blindly and thus badly affected several related me tabolic processes. On contrarily, the herbal drugs probably have more accuracy in working, more effective, target specific action and without side effects. Further the drugs are affordable, eco-friendly and easily available in local market.

About the study area:

Bhandardara is a pleasant hilly place occure as one of the spur of Sahyadri Mountain. it is situated $185 \mathrm{Km}$ (i.e. 115 miles) away from Mumbai. It is surrounded by the dense forests of ethnobotanical interests. The area under the study is an ideal hill station famous for diverse ethno-flora. It is situated at distance of $75 \mathrm{~km}$ on North-western side of Ahmednagar district (M.S.) India. It covers an area of $214.10 \mathrm{~km}^{2}$ (i.e. 468.8 miles $^{2}$ ) and lies at an altitude of 394-413 meters from MSL (Mean Sea Level) and is located in between $19^{\circ} 31^{\prime} 40^{\prime \prime} \mathrm{N}-19^{\circ} 33^{\prime} 43^{\prime \prime} \mathrm{N}$ latitude and $73^{\circ} 45^{\prime} 50^{\prime \prime} \mathrm{E}-73^{\circ} 497^{\prime}$ ” E longitude. The area under the study is occupied by forest area of $44.26 \mathrm{~km}^{2}$ with $52.5 \%$ mixed-deciduous forests with an average rainfall of about $635 \mathrm{~mm}$ (2008) and temperature range of $12^{\circ} \mathrm{C}$ to $36^{\circ} \mathrm{C}$ [3]. So far the study concerned, area under the study is unexplored up to today.

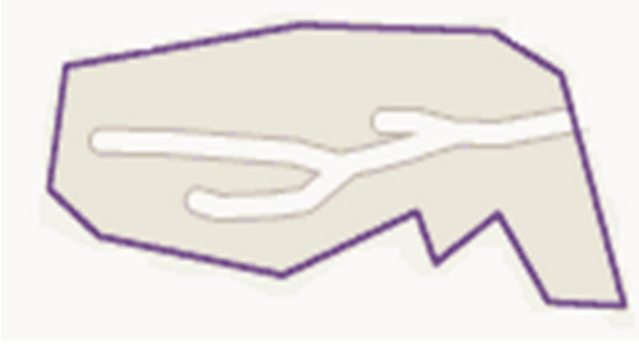

Figure: 1 Study area: Bhandardara

Review of literature:

Recent interest in ethno-medicinal explorations has increased due to the work of [3-11]

\section{Methodology:}

a structured and semi-structured interviews [12] were arranged in the study area season wise during the period from June 2009 to October 2011 to collect the data regarding ethno-medicinal uses of the native ethno-flora from the local inhabitants. The plant specimens were collected and identified by their local names, with the help of local traditional healers and medicine men as per guidelines [13-15]. The ethno-medicinal information was confirmed orally through help from the local traditional healers and medicine men via verbal and informal interviews.

The voucher specimens were prepared, tagged and confirmed by referring the standard floras [16-20]. They were preserved as per plan suggested by [21] in the Department of Botany, Shri Dnyaneshwar Mahavidyalaya, Newasa for future study. 


\section{Result/ Enumeration:}

1. Abelmoschus mannihot (L.) Medik. 'Ranbhendi' (Malvaceae)

Habit: Herb

Occurrence: Common

Plant part :Le af

Use: Young and tender leaves of the plant are chewed by the live traditional singers to improve tutoring speech.

2. Acacia leucophloea (Roxb.)Willd. 'Hiwar' (Mimosaceae)

Habit: Tree

Occurrence: Common

Plant part : Root

Use: Paste from one to two gram of fresh roots in $10-15 \mathrm{ml}$ warm water is applied topically on painful gums once daily up to $15-18$ days to cure gingivitis.

3. Actinopteris radiata (Sw.) Linn., syn. A. dichotoma Be dd.' Bhui-tad' (Actinopterid aceae).

Habit:Fern

Occurre nce :Rare

Plant part : Leaf

Use: 1-2 tolas (aprox.10-20 gm) leaves powder is boiled in aatpav (100 ml)water for 5-7 minutes and the decoction is applied topically on painful teeth once a day in the early morning to cure toothache.

4. Aegle marmelos (L.) Corr. 'Bael' (Rutaceae).

Habit:Tree

Occurre nce :Rare

Plant part : Leaf

Use: Aatpav (aprox.100 gm) young leaves are crushed in a cupful of goat's milk and the extract is given with 1-2 tsp of honey twice a day up to 5-8 days to cure diarrhea and dysentery.

5. Ailanthus excelsa Roxb. 'Maharukh'

(Simaroubaceae)

Habit:Tree

Occurre nce :Common

Plant part : stem (bark)

Use::Shade dried stem bark pieces are crushed with 2-3 dried nilgir (Eucalyptus globulus) le aves and 1-2 tolas of Arjun sadada (Terminalia arjuna) stem bark pieces and the fine powder is used as tooth powder once daily in early morning to relieve from toothache.

6. Anogeissus latifolia (Roxb. ex DC.) Wall. ex. Guill \& Perr. 'Dhamboda' (Combretaceae)

Habit:Tree

Occurre nce :Rare

Plant part : stem (bark)

Use: 1-2 tolas (aprox.10-20 gm) of fresh root pieces are crushed and is taken in mouth two times in a day for 3-4 days to get relief from toothache.
7. Artemisia nilagirica (C.B.Cl.) Pamp. 'Dhordavana' (Asteraceae)

Habit:Shrub

Occurrence:Rare

Plant part : Leaf

Use: An extract from fresh leaves is mixed in a applied painful muscles of joints to relieve arthritis and rheumatism.

8. Bombax ceiba Linn. 'Kate-sawar' (Bombacaceae)

Habit: Tree

Occurrence: Rare

Plant part : Stem (bark)

Use: Fresh latex from the plant is applied on teeth as toothpaste once daily for 10-12 days to heal wounds in pet animals.

9. Caesalpinia decapetala (Roth.) Alst. 'Chillar' (Caesalpinaceae)

Habit:Shrub

Occurrence:Rare

Plant part : Leaf

Use: Fresh leaves are boiled with tea powder in cup of goat's milk is given twice a day for 3-4 days to control gingivitis and pyorrhoea.

10. Caesulia axillaris Roxb. 'Kala-maka' (As te raceae)

Habit:Herb

Occurrence:Common

Plant part : Le af

Use: *Fresh and healthy leaves of the plant are boiled in coconut oil and the preparation is used to attain healthy and fast hair growth.

11. Caralluma adscendens var fimbricata (Wall.) Gravely \& Mayumath. 'Shindal-makadi' (Asclepiadaceae)

Habit:Herb

Occurrence:Rare

Plant part : Stem

Use: Fresh leaves are chewed regularly early in the morning upto 8 days by the inhabitants to cure mouth sores and ulcers

12. Holarrhena pubescens Wall. ex G. Don. 'Safed kuda' (Apocynaceae)

Habit:Tree

Occurrence:Rare

Plant part : Latex

Use: A tablespoon fresh latex is mixed in a half litre of cow's milk to make curd.

13. Ipomoea carnea Jacq. ssp. fistulosa (Mart. Ex Choisy) Aus tin 'Bes hram' (Convolvulaceae)

Habit:Herb

Occurrence: Common

Plant part : Leaf

Use: an extract from fresh leaves in ordinary liquor is applied externally on the skin suffe ring from cryptococcosis twice a day up to $12-15$ days to cure infection. 
14. Jatropha gossypifolia Linn.'Mogali erand' (Euphorbiaceae)

Habit: Shrub

Occurre nce :Rare

Plant part : Latex

Use: Latex from the plant mixed in mixture of mohri (Brassica compestris) seed oil and clove (Syzygium aromaticum)fruit oil (5 $\mathrm{ml}$ each) and the formulation is applied on painful legs of pregnant women once daily at night from seventh month up to $10-12^{\text {th }}$ days after de live ry.

15. Milingtonia hortensis L. f.

'Hirda'(Bignoniaceae)

Habit: Tree

Occurre nce : Rare

Plant part: Whole plant

Use: *To increase fertility and chances of conception, women willing to pregnant, remain in close association of this tree in flowering pe riod.

16. Spilanthus oleracea Linn. 'Akkalkara'

(Asteraceae).

Habit:Herb

Occurre nce :Rare

Plant part : Inflore scence

Use: A handful of fresh inflorescence axes are crushed in a cupful of goat's milk and resultant preparation is consumed once daily in the early morning up to 6-8 days to cure pyorrhoea and gingivitis.

17. Tephrosia perpurea (Linn.)Pers. 'Unhali' (Fabaceae).

Habit:Herb

Occurre nce: Common

Plant part : Root

Use: A handful of root powder and 1-2 tsp of honey are boiled in a glass of goat's milk and the formulation is given internally twice a day up to 6-10 days to cure toothache and pyorrhoea.

18. Terminalia arjuna Retz. 'Arjuna'
(Combre taceae)

Habit: Tree

Occurrence:Rare

Plant part : Fruit

Use: Homogeneous mixture from fruit powder with specific quantity of shatawari (Asparagus racemosus) tuber powder is used regularly as health tonic for anti-ageing.

19. Terminalia chebula Retz.

'Hirda'(Combretaceae)

Habit:Tree

Occurrence:Rare

Plant part : Fruit

Use: *Pericarp from 2-3 ripen fruits is boiled in a cupful cow's milk and the resultant formulation is consumed once daily in early morning for 3-4 weeks increase and maintains sexual vigour and strength in sexually weak men .

\section{Discussion:}

The present paper illustrated a brief account of 19 plant species belonging to 17 gene ra from 14 families used for the treatment of specific kind of healthcare practices in Akole tahasil from Ahmednagar district (M.S.) India. Almost all of the preparation/formulations are administered orally eithe $r$ in the form of extract or juice.

From above study (Table:2), it is found that leaves in seven plants (36.84\%) which is followed with roots in five plants each $(26.32 \%)$, fruits in three plants (15.79\%) and stem and latex in two plants each (15.79 \%).found to have unique role in healthcare practices.

Table: 2-Plant part used against name and number of plant species studied:

\begin{tabular}{|c|c|c|c|c|}
\hline S.N & $\begin{array}{l}\text { Part } \\
\text { used } \\
\text { Leaf }\end{array}$ & $\begin{array}{l}\text { Name of plant species } \\
\text { Ipomoea carnea Jacq. ssp.fistulosa (Mart. Ex. Choisy) } \\
\text { Austin., Caesulia axillaris Roxb.,Caesalpinia decapetala } \\
\text { (Roth.) Alst.,Artemisia nilagirica (C.B.Cl.) Pamp., Aegle } \\
\text { marmelos (L.) Corr., Abelmoschus mannihot (L.) Medik , } \\
\text { Actinopteris radiata (Sw.) Linn., }\end{array}$ & $\begin{array}{l}\text { No of } \\
\text { species } \\
07\end{array}$ & $\begin{array}{l}\% \text { of plant } \\
\text { part used } \\
40.00\end{array}$ \\
\hline 2. & Ste $\mathrm{m}$ & $\begin{array}{l}\text { Caralluma adscendens var fimbricata (Wall.) Gravely \& } \\
\text { Mayumath., Ailanthus excelsa Roxb.,Bombax ceiba L., } \\
\text { Anogeissus latifolia (Roxb. ex DC.) Wall. ex. Guill \& Perr. }\end{array}$ & 04 & 20.00 \\
\hline 3. & Latex & $\begin{array}{l}\text { Jatropha gossypifolia Linn., Holarrhena pubescens Wall. ex } \\
\text { G.Don. }\end{array}$ & 02 & 10.00 \\
\hline 4. & Root & $\begin{array}{l}\begin{array}{l}\text { Tephrosia perpurea (Linn.)Pers., Acacia leucophloea } \\
\text { (Roxb.)Willd., }\end{array} \\
\end{array}$ & 02 & 10.00 \\
\hline 5. & Fruit & Terminalia arjuna Retz., Terminalia chebula Retz. & 02 & 10.00 \\
\hline 6. & Inflo. & Spilanthus oleracea Linn. & 01 & 5.00 \\
\hline 7. & $\begin{array}{l}\text { Whole } \\
\text { plant }\end{array}$ & Milingtonia hortensis L.f. & 01 & 5.00 \\
\hline
\end{tabular}




\section{Conclusion:}

The area under the study is bestowed with a great ethno-floristic diversity. It denotes the wisdom of the local people including the traditional healers and medicine men in regards to traditional ethno-medicinal knowledge. It enlightens immense scope and wide potential for research in the ethnobotanical science. To document, conserve and evaluate the information, collective efforts are needed from the ethno-botanists and ethno-pharmacologists be fore it disappeared. As an ethno-botanist, it's our prime duty to protect, document and spread the indigenous traditional knowledge through various media and overcome the problems of biotic and abiotic interfe rence and deforestation. To conserve it, urgent need of collaborative work on rural and tribal level through participation activities of the rural, tribal and non-tribal populace, semi-government and government authorities is essential which will create general awareness among the $\mathrm{m}$ about the conservation of the native ethno-flora.

The central and state government authorities should encourage the ethnobotanists and ethno-pharmacologists in exploration of the hidden ethnobotanical wealth in the se areas which will help in elevating the export of herbal medicine and growing the trade and economy of the country by increasing herbal trade with the major countries around the world. This will also improve the health and quality of life of this entire nation.

\section{Acknowledgement:}

Author's thanks are due to the help rendered by the notified and de-notified rural, tribal and traditional healers from the study area due to their immense help and cooperation during the study and field work. Thanks are also due to the authorities of Forest division of Ahmednagar for immense cooperation and permission for collection of plant parts from plants of ethno-medicinal significance.

\section{References:}

1. Hedberg, I.(1993).Botanical methods in ethno-pharmacology and the need for conservation of medicinal plants.J. Ethnopharmacol. 38: 121-28.

2. Fansworth, N.R. (1988). Screening of plants for new medicines. In: Wils on E O. Biodiversity. Washington DC: Nac. Acad. Oress, 521

3. Gazetteer of Bombay Presidency, Ahmednagar, 1884.

4. Mehrotra, S. and Mehrotra B.N. (2005).Role of traditional and folklore herbals in the development of new drugs. J.Ethnobot. 17: 10411 .

5. Pei, S.J.(2001) Ethnobotanical approaches of traditional medicine studies some experiences form Asia, J. Pharmaceutical Biol,39:74-79.

6. Jain S.K.(1991).Dictionary of Indian Folk Medicine and Ethno botany, Deep Publications New Delhi.

7. Gayake1, D.N., Awasarkar U.D.and Sharma P.P. (2013).Indigenous Traditional Medicinal Plant Resources from Ahmednagar District, Maharastra, India.Asian Journal of Biomedical and Pharmaceutical Sci. 3(22)1-5.

8. Petkar A.S., Wabale A.S., Shinde M.C. (2002).Some Ethnomedicinal Plants in the tribal areas of Akole and Sangamner talukas of Ahmednagar District (M.S). J.Indian Bot. Soc. 81:2 13-215.

9. Wabale, A.S. and Petkar A.S.(2005).Ethno medicinal plants used against Jaundice by the Tribals of Akole taluka (M.S.) J. Phytol. Res. 18(2):259-261 .

10. Khyade, M.S.,Wani,P.S.,Awasarkar U.D.and Patkar A.S.(2008).Ethno medicinal Plants used in the treatment of Toothache By Tribals of Akole, Ahmednagtar (M.S.), J.Enrich Environment, 76-80.

11. Jain, S.K.(1967).Ethnobotany: Its scope and study in India. J. Museum Bull.2 (I):39-43.

12. Alexiades, M.N. and Sheldon J.W.(1996) Selected guidelines for ethnobotanical research: A field manual. New York Botanical Gardens. Bronx. New York. USA.

13. Jain SK, Rao RR (1967).A handbook of field and herbarium methods, Today and Tomorrow

Printers and Pulishers, New Delhi, 33-58.

14. Jain, S.K. and Mudgal V.A.(1999).A Handbook of Ethnobotany, Bishen Singh Mahendra Pal Singh, Dehradun, 58-63.

15. Jain, S.K.(1989).Methods and approaches in Ethnobotany, Society of Ethnobotanists, C.D.R.I., Lucknow, 127-31.

16. Almeida, M.R.(1996).Flora of Maharashtra. Blatter Herbarium, St. Xavier's College, Mu mbai, 369p.

17. Cooke, T.(1958).The Flora of the Pre sidency of Bombay, Vols $1 \&$ II, Repr. edr, Government of India, 357.

18. Pradhan, S.G. and Singh N.P.(1999).Flora of Ahmednagar District.(M.S.),Bishen Singh Mahendra Pal Singh. Dehradun 339.

19. Singh, N.P.,Lakshinarshimhan P. and Prassanna P.V.(2001).Flora of Maharashtra State Vol. II, Bot. Surv. India, Calcutta, India.

20. Singh, N.P. and Kartikeyan S. (2002).Flora of Maharashtra State, Vol II., Bot. Surv. India, Calcutta.329p.

21. Schulte, R.E.(1968).The role of Ethnobotanists in search for new medicinal plants. J. Lloydia, 25 (4):257-66. 